\title{
Ways of Destructive Cults to Steal Religious Affections
}

\author{
LV Li, YAN Mei-fu, XIE Gui-yang \\ Hubei University, Wuhan, China
}

\begin{abstract}
Religious affection is a kind of emotional experience that religious believers have to the gods after they have participated in religious activities and experienced religious rituals. Religious experience is what connects individuals and the gods. It can lead people to believe in religion and strengthen people's religious beliefs and is the basis of the establishment, dissemination and consolidation of religions. This article reveals that extreme cults create illusions for believers by conducting information and time control, making them exhausted physically and mentally and using "social hypnosis” and that they have stolen traditional religious affection and religious experience for their own usage by inducing believers religious affection through self-praise, intimidation and deception and wide insinuation.
\end{abstract}

Keywords: destructive cults, religious affection, religious experience, social hypnosis, illusion

\section{Introduction}

Some Western countries have a laissez-fair attitude towards extreme cults at the very beginning, but when the cults grow detrimental to lives and society, they usually surpass them by force. But because of the differences of cultural traditions, China has had different ways to deal with cults and every government in Chinese history never tolerated them. As a result, this time when cults began to revive in Chinese Mainland, the religion circle and social science circle revealed and criticized them because they tampered the doctrine and teaching of orthodox religions and embezzled the emblem and concept of orthodox religions by using Buddhism and Christian as the guise and employing god and Buddha as the mark and pretended to be orthodox religions to solicit and delude believers in order to expand their organization. However, the revelation and criticism on their stealing of the religious affection and experience which traditional religions rely on in the course of establishment and dissemination are not complete. And this article tires to supplement the deficiency.

\section{Religious Affection and Religious Experience are the Determinants of Religious Beliefs}

\section{Religious Affection}

Religious affection is a kind of emotional experience of reverence, dependence, respect, admiration and gratitude that religious believers have spontaneously to the gods after they have known the doctrines and teachings of religions, participated in religious activities and experienced the solemn and respectful religious rituals. And once this kind of emotion comes into being, it will enhance and strengthen the believers' religious

LV Li, Lecturer, Department of Psychology, Hubei University.

YAN Mei-fu, Professor, Department of Psychology, Hubei University.

XIE Gui-yang, Associate Professor and Postgraduate Tutor, Department of Psychology, Hubei University. 
beliefs. Given that deity, the object of religious belief, is an invisible and indescribable mystery, religious belief is irrational, which means that it is not gained by ration but by the individual's emotional experiences. As a result, religious affection plays a salient and primary role in the formation, consolidation and enhancement of religious belief. In other words, the establishment, dissemination and consolidation of traditional religions mainly rely on religious affection.

\section{Religious Experience}

Religious experience is a kind of experience which symbolizes the individual's connection with the gods and there are two ways to gain it.

Religious believers' ways to get religious experience. Religious believers' pretersensual religious experience is gained by practices, worship and religious activities. When believers get religious experience, they will gain high-spirited enjoyment and they can even enter a mystical state where they can reach the unity of mind and material, and forget everything in the outer world. Maybe they witness the images of the gods, maybe they see Buddha's light shine. Or they hear sounds of nature and feel that they themselves have integrated with the entire universe.

Some reverent religious believers claim that they have got this kind of religious experience. Once one has such kind of mysterious experience in believing religions, he will devote himself or herself to religions heart and soul. Because at that moment, not only has he felt the communication, connection and integration between the gods and him directly, but also he has experienced the impressively grand, marvelous, reverent and solemn atmosphere, which will make him create a sense of indefinite awe, surprise, reverence, dependence and peace.

Common people's (non-religious believers') religious experience. This is an indescribable mysterious gods-related experience that common people create after their participation in religious activities and rituals and sacrifices on traditional festivals. For people who have never had any religious experience, it is difficult for them to understand what is contained in it no matter how hard you have tried to describe it to them. But for those who have had such kind of experience, though their experience is various, in general, their religious experience is similar to the "peak experience" proposed by Maslow, who is a humanism psychologist. What they have experienced is not the presence of the gods, the communication between the gods and human beings or going to heaven or going down to hell but the overwhelming reverence in that single moment or the transient extremely intense happiness. For them, this is a kind of marvelous and obscured "ocean-emotion" or mysterious experience that is god-like and wide enough to cover the whole universe. A number of people claim that they have witnessed the ultimate truth, the essence of materials and the secrets of life from this kind of experience.

Religious experience is the individual's subjective feeling which can leave people with strong impression and even huge shock. And it is so peculiar, odd and hard to understand that different people may have different reactions. They may feel confused, excited, yearning for it or terrified. And some people may strengthen their belief in supernatural beings. Some people who did not use to believe in religions may believe because of it and some religion believers may become more pious. Consequently, over the past thousands of years, traditional religions have led people to believe in religions by religious affection and experience to establish, develop and consolidate religions. As a result, the celebrated contemporary religious scholar Vaha says: "the determinants of religions are not their continuously changing ideologies, etiquettes and regulations but the religious affection and 
experience of the integration of the gods and people. And religious affection and experience is the basis, core and starting point of all religious phenomenon”.

\section{How Do Cults Embezzle Religious Affection and Religious Experience}

Extreme cults learn it from traditional religions or realize that religious affection and religious experience play the core role in the formation, dissemination and consolidation of religions, so they embezzle them to serve for the establishment and development of their heresies. However, the reason why traditional religious make believers develop religious affection and experience is that they not only have their own classics, doctrines, rituals and religious discipline, but also they require believers to study the classics hard, comprehend the doctrines in a deep sense and observe the religious rules and disciplines strictly. Believers develop their religious affection and experience spontaneously in the course of studying the classics attentively and observing disciplines strictly and in their reverent practices like regimen, meditation and pray and in the solemn and divine atmosphere of religious activities. The clergies of traditional religions such as bishops, abbes, priests, Buddhist abbots, monastic mangers, imams and Akhoods lead believers to abandon selfish interests and unorthodox ways and be concentrated on religious practices, but they will never make lies or mysterious manifestations to induce believers' religious affection and experience.

But extreme cults are just the opposite. After embezzling religious affection and experience from traditional religions, they adopt various ways to induce believers' religious affection and experience and make believers believe the mysterious manifestations they create so that believers will respect, worship and even rely on their hierarch and believe in them and follow the hierarch yearningly and desperately. For example, Eastern Lightening wrote down characters on the ground with sweet water or honey to attract ants that crave sugar and the accumulated ants presented the image of those characters, which was the illusion that "ants write". And they put notes inside the fish and claimed that it was the coming of the gods. They cheated people in such ways.

Of course, these are just some simple ways that extreme cults used to get believers' religious affection and experience. Besides, they are more likely to make believers develop religious affection and experience in some psychological methods, mainly including as follows.

\section{The Creation of Hallucination}

Cults induce believers to develop hallucination by various ways and make them take it as religious experience. specifically, the ways are:

Information control over believers. According to psychological studies, if one is separated from the external environment for a long time and is accessible to limited information and only receive monotone stimulation, which is in the state of "sensory deprivation" in psychology, he will develop hallucinations and even have such mental disordered symptoms as delusion. Evil organizations that know this well cut believers off from news and ask them to read, memorize and recite the hierarch's utterances, books, lections, videos and audio tapes attentively and search their conscience. Believers are prohibited from reading other books, listening to the radio, reading magazines and watching TV. And cults reject all the so-called "negative information" that is detrimental to them so that believers don't have any other references. Asahara, the founder of Japanese Aum Shinrikyo, did it in this way. He asked believers to watch his teaching videos and study and recite his books and sermons continuously and repeatedly. And he required them to spend 16 to 20 hours each day to practice the ritual of 
prostrating themselves on the ground and chant "Aum, the mentor, the Shiva, please guide me now" at the same time. So did Li Hongzhi, the founder of Fa Lun Gong in China. Under the excuse of "the only proper course to take”, he forbades believers from reading other books and doing other exercises. Believers were banned from reading newspapers, watching TV and listening to broadcasts, they could only read, watch and recite Fa Lun Gong and the lections, which caused that many believers abandon all their habits and spend all their time reading, transcribing and reciting the book and lections. Some believers could recite many paragraphs of the book, some could write down the lections without any mistakes and some could even translate the book into English and transcribe it down neatly. Stimulated by this single and monotonous information, believers' mind were occupied by Fa Lun Gong. Consequently, some believers claimed that they had opened "the wisdom eye" and had peeped at the wheel of dharma and the world of it and gained religious experience. In fact, they just generated hallucinations.

The extreme cults make believers generate religious experience by exerting time control over believers and make them exhausted mentally and physically. Believers of Aum Shinrikyo can only have one meal a day. And they can only have a small piece of bread, a small bowl of noddle, a bowl of soup and a small hamburger. But they are asked to do all kinds of things and even heavy physical works. And believers who have made mistakes have to repeat three kinds of practices: they have to spend four hours learning the Tibetan Buddhist ritual of prostrating themselves on the ground, three hours in learning air breathing and one hour in meditation. And they can only sleep and take a short break when they are in meditation

Fa Lun Gong also deprives its believers' time in various ways. First, practice takes up two hours each in the morning and in the evening. Second, there is no time limit of "investigating the Dharma". Third, believers have to participate in the cults' activities such as "the transmission of Dharma" and "communication". Given that time is limited, some believers even deprive their own sleeping time, which makes themselves extremely exhausted. But psychological studies show that people are very likely to have hallucination when they are extremely exhausted. Once believers began to have hallucinations, Li Hongzhi claimed that they had opened the wisdom eye and got the function of remote viewing, making them believe that they had gain religious experience.

The use of "social hypnosis". The cults make believers generate hallucination by using social hypnosis. Different from the public hypnosis conducted by common hypnotists, social hypnosis is covert. The hypnotists of it are those self-given “Archmage”, "great Qigong doctors” and leaders of cults. Social hypnosis is conducted in the course of practicing, learning and praying and the hypnotists will never tell you that they are hypnotizing you and you don't know that you are being hypnotized. "Social hypnosis” is conducted on the basis of information and time control over exhausted believers. Psychological researches show that the decreasing of external stimulation and the continuous deprivation of time will reduce the recalling ability of cerebral cortex and raise the level of alcohols hormone, causing the disorder of emotion, recognition and behavior and leading to unresponsiveness, the decreasing or even loss of judgement. Consequently, people enter the state of hypnosis. In this state, believers' mind is unsuspecting so that the heretical ideas and false claims can go through the consciousness and enter into the subconscious. But at that moment, the boundary between consciousness and subconscious is obscure and the former has a loose control over the latter, so what is in subconscious can go back to the consciousness, therefore, people may generate hallucination and illusion. But the obsessed believers don't know this is hallucination, they think that it is because their level has been lifted and they have seen mysterious 
manifestations and realized the communication with the gods after strenuous practices.

Chinese people always hold the idea that "seeing is believing", although what they see is just the hallucination in the state of hypnosis, they don't believe that what they have seen is illusion. The author have a student who majors in computer called Yang XX, a 30-year-old man. He is simple, honest and mild. He claimed that he had opened the wisdom eye and witnessed the hell for several times where he saw his grandfather had become a pig and was taken by someone. Some relevant experts explained that his opening of wisdom eye was a kind of hallucination and illustrated the causes of it. But Yang XX still could not believe it because he could not deny what he had witnessed. But even experts didn't know how to make him believe what he had seen was his own hallucination instead of the opening of wisdom eyes because psychology could only explain the causes of hallucination inferentially in terms of secluded environment, interrupted information, over fatigue, the acceptance of insinuation, drug effects and nervous emotion and could not demonstrate the creation of hallucination to Yang XX and make him generate the hallucination that his grandfather had become a pig in the hell and was taken away, which makes such a simple, honest and practical man with slow thinking can't get rid of cults.

\section{Inducing Believers’ Religious Emotion by Self-praise, Intimidation and Inception as Well as Wide Insinuation}

Self-praise. This is the most common method used by all the founders of cults to induce believers' religious affection and experience. Jim Jones, the founder of the People's Temple, claims himself to be God; Vernon Howell ,the founder of the Branch Davidian, claims himself to be reanimated Jesus; Berger from "the Children of God” claims that he is the king selected by God; Ji Sanbao from Men Tu Hui claims himself to be Christ selected by God; Liu Jiaguo, the founder of Henotheism, claims that he himself is god and Li Hongzhi, the founder of Fa Lun Gong, claims that he is the greatest and most divine Buddha in the universe and the king of all the kings, besides, he claims that he can control all the people and the entire world in an easy manner. Those daydream and impractical boasts will inevitably cause criticism from people with scientific knowledge, but they hit the religious affection of worship and resilience in humanity. People always feel that they are weak and vulnerable in front of the changing nature and society and they believe that they can be saved and exempted from disasters by some supernatural forces, which makes the founders of cults realized that they can stimulate people's awe and dependence if they boast that they are equipped with great supernatural forces.

Deception and intimidation. This is the second method that cults used to make believers develop religious affection. The first one is deception. Jim Jones, the founder of the People's Temple, lied to the believers that he could cure lethal disease such as cancer like Jesus. And he passed chicken livers and gizzards off as tumors and performed the removal of tumors for the patients. Ji Sanbao, the founder of Men Tu Hui, lied that he could make the blind regain their sight, make the paralyzed stand up again, make the mute speak and reanimate the dead kids by praying. Li Hongzhi's tricks are more deceitful. He claimed that he can put Qi function and the wheel of dharma inside the believers and could make them go to heaven and become the gods and Buddha and be immortal in heaven.

The next one is intimidation. Li Hongzhi said if you don't listen to him, he will get the wheel of dharma back that he has gave to you and take away the Dharmakaya and the Qi function that is sent to protect you and he will 
get the removed karma back to you. He will not protect you anymore. At that time, your life can be taken away by the "demon"! Beili Wang said: "the end of the world is coming and the earth is going to be destroyed, a lot of people will die and sixty percent of human being in earth will wither away in two years". It is obvious that if you believe those deception and intimidation, your religious affection will come into being spontaneously.

Wide insinuation. If deceptions don't work, cults will induce the believers' affection and experience by insulation. For example, Li Hongzhi changed his birth date to the birth date of Buddha. And he made the figure of Buddha of himself sitting in the Lotus Petal to suggest that he was the reincarnation of Buddha who was sent by Buddha to be awed and respected by people.

\section{References}

CHEN, Z. M. ( 2001). The truth of cult. Beijing: The Contemporary World Press.

LV, D. J. (1999). New general theory of religion. Beijing: Social Sciences Academic Press.

LV, H. R., \& XIN, S. J. (2003). The mystery of the religious. Zhengzhou: Henan People Press.

Mary, J. M. (1988). The psychology of religion. Sichuan: Sichuan People’s Press.

TAI, Q. Y. (2005). The hypnosis. Beijing: Social Sciences Academic Press.

WANG, D. W. (2001). Cults and anti-cults movement in American history. Nanning: Guangxi People Press.

WANG, J. P. (2005). Abnormal psychology. Beijing: Higher Education Press.

WANG, Q. H., ZHU, M., \& LI, G. C. (2007). History of the Chinese cult. Beijing: qun zhong Press.

WANG, Z. C. (2002). The psychiatry. Beijing: People's Medical Press.

ZHANG, C. X. (1994). Modern psychology. Shanghai: Shanghai People’s Press.

ZHAO, X. C. (2010). The dialysis of Falun gong. Jinan: Shandong Culture Audio and Video Press. 